\title{
11-Beta-Hydroxysteroid Dehydrogenase Type 1 Deficiency
}

National Cancer Institute

\section{Source}

National Cancer Institute. 11-Beta-Hydroxysteroid Dehydrogenase Type 1 Deficiency.

NCI Thesaurus. Code C131084.

Decreased activity of the enzyme 11-beta-hydroxysteroid dehydrogenase type 1 due to inactivating mutation(s) in the HSD11B1 gene. The condition is characterized by hyperandrogenism as a result of increased adrenocorticotropic hormone stimulation of the adrenal gland due to failure of cortisol-mediated down-regulation, and is clinically indisting uishable from H6PD deficiency. 